\title{
An Assessment of Birth Registration System and Factors Affecting in India and its States
}

\author{
Nutal Kumari \\ International Institute for Population Sciences, India \\ Objective
}

To see the level and trend of the vital registration system in India and its states form 2005-2015. To identify factors influencing civil registration in India

Introduction

Civil Registration system (CRS) in India has been in vogue for more than 100 years now. The registration of Birth and Deaths Act, 1969 came into force in 1970. Even after 4 decades of the enactment of the act, there are wide inter-state and intra-state variations. India is the second largest populated country in the world after China. Whereas as the level of registration of birth and deaths varies from (84.4 and 69.3) registrations. In India, more than 250 thousand of registration centers are involved in central registration system and estimated births per years are 26 million, and the corresponding figure for death is 8 million (Sethi 2016).

\section{Methods}

The present study uses National family health Survey (NFHS) 3 and 4 used for the analysis to see an assessment of birth registration system and the factors affecting in India and its states. Multivariate analysis used to see the effect of a socio-demography factor that affects the registration of birth.

\section{Results}

Figure 1 presents information on prevalence birth registration under age five years with civil authority in India from NFHS- 3 and NFHS-4; this includes 27 percent (NFHS -3) 62 percent of children with birth certificates and 14 percent (NFHS- 3) 18 percent are children which has registered the birth but don't have certificate. Table 1 demonstrates Prevalence of children under age five whose birth is registered with the civil authorities in India and its states from NFHS-3 and NFHS-4. Birth registration among children under age five years double between NFHS-3 and NFHS -4 (from $41 \%$ to $81 \%$ ). However, there is also an increase in all the states of India from 2005 to 2016 . The percentage of births that were registered increase by more than 50 percentage points between 2005-06 and 2015-16 in Jharkhand, Bihar, Uttar Pradesh, Madhya Pradesh, and Rajasthan

Table 2 present the percentage of children under age five years whose birth was registered with civil authorities accounting to background characteristics. The registration of birth was high in age group less than 2 in NFHS -3 (79\%) but in NFHS -4 high in 2-4 age group (53\%). The registration of male is high in NFHS- and NFHS-4 (52\%) as compared to a female child (48\%). In the religion, the registration is high in Hindu in both the survey. However, in caste, the low registration are found in Scheduled caste (NFHS- $3(19.2 \%)$ \& NFHS- $4(21.4 \%)$ ) and scheduled tribal. With the increase in wealth index, there is an increase in the birth registration system.

\section{Conclusions}

Birth registration and subsequent issuance of a certificate do not only promote human rights to citizenship but it also facilitates human rights to good health, education, social security, and overall human development. Therefore, timely registration of children should be pursued as a right issue. This study found that high levels of birth registration were related to a high level of awareness among the urban population regarding birth registration. However, findings of this study seem to suggest that it is more of a privilege for children whose parents are educated, wealthy and live in urban areas.

\section{References}

1. Sethi RC. Civil Registration System, Sample Registration System \& Annual Health Survey: Issues and Policy Uses. The Global Summit on CRVS. http://www.slideshare.net/kdcgroups/ session-5a-rcsethi accessed on 10/10/2016. 
ISDS 2019 Conference Abstracts

Table 1

\begin{tabular}{|c|c|c|}
\hline States & NFHS-3 & NFHS-4 \\
\hline Andhra Pradesh & 40.3 & 84.6 \\
\hline Arunachal Pradesh & 33.6 & 66.0 \\
\hline Assam & 44.1 & 94.8 \\
\hline Bihar & 6.2 & 62.9 \\
\hline Chhattisgarh & 73.0 & 87.6 \\
\hline Goa & 89.2 & 99.2 \\
\hline Gujarat & 88.2 & 97.4 \\
\hline Haryana & 72.7 & 94.8 \\
\hline Himachal Pradesh & 90.1 & 96.8 \\
\hline Jammu and Kashmir & 36.6 & 79.4 \\
\hline Jharkhand & 9.5 & 67.4 \\
\hline Karnataka & 59.7 & 97.5 \\
\hline Kerala & 95.9 & 98.5 \\
\hline Madhya Pradesh & 29.8 & 84.6 \\
\hline Maharashtra & 81. & 95.4 \\
\hline Manipur & 30.6 & 67.4 \\
\hline Meghalaya & 44.0 & 81.4 \\
\hline Mizoram & 93.2 & 98.5 \\
\hline Nagaland & 37.0 & 70.6 \\
\hline Odisha & 58.7 & 84.0 \\
\hline Punjab & 77.6 & 98.7 \\
\hline Rajasthan & 16.4 & 69.2 \\
\hline Sikkim & $85 . .7$ & 98.8 \\
\hline Tamil Nadu & 85.7 & 98.5 \\
\hline Tripura & 75.3 & 91.6 \\
\hline Uttar Pradesh & 7.3 & 62.3 \\
\hline Uttarakhand & 40.2 & 80.5 \\
\hline West Bengal & 76.2 & 96.8 \\
\hline Telangana & - & 85.6 \\
\hline
\end{tabular}


ISDS 2019 Conference Abstracts

Table 2

\begin{tabular}{|c|c|c|}
\hline \multicolumn{3}{|c|}{ Age } \\
\hline$<2$ & \multicolumn{2}{|c|}{78.8} \\
\hline $2-4$ & 21.2 & 52.9 \\
\hline \multicolumn{3}{|l|}{ Place of residence } \\
\hline Urban & 37.0 & 31.4 \\
\hline Rural & 63.0 & 68.6 \\
\hline \multicolumn{3}{|l|}{ Sex } \\
\hline Male & 52.0 & 51.8 \\
\hline Female & 48.0 & 48.2 \\
\hline \multicolumn{3}{|l|}{ Mother } \\
\hline No schooling & 28.1 & 5.0 \\
\hline$<5$ years complete & 15.6 & 17.2 \\
\hline 5-7 years complete & 46.2 & 28.4 \\
\hline 8-9 years complete & 10.1 & 49.4 \\
\hline \multicolumn{3}{|l|}{ Religion of household head } \\
\hline Hindu & 76.6 & 78.6 \\
\hline Muslim & 16.7 & 16.5 \\
\hline Christian & 2.7 & 2.2 \\
\hline Sikh & 2.4 & 1.6 \\
\hline Buddhist/Neo-Buddhist & 1.2 & 1.0 \\
\hline Other & 0.4 & 0.2 \\
\hline \multicolumn{3}{|c|}{ Caste/tribe of household head } \\
\hline Scheduled Caste & 19.2 & 21.4 \\
\hline Scheduled trible & 9.2 & 10.0 \\
\hline Other backward class & 35.2 & 42.3 \\
\hline Other & 35.9 & 26.3 \\
\hline \multicolumn{3}{|l|}{ Wealth Index } \\
\hline Lowest & 14.3 & 19.8 \\
\hline Second & 16.7 & 21.1 \\
\hline
\end{tabular}

cont.. 
Figure 1: Prevalence of Birth Registration Under Age Five Years with Civil Authority in India from NFHS-3 and NFHS-4

Figures 1 Prevalence of Birth registration under age five years with civil authority in India from NFHS-3 and NFHS-4

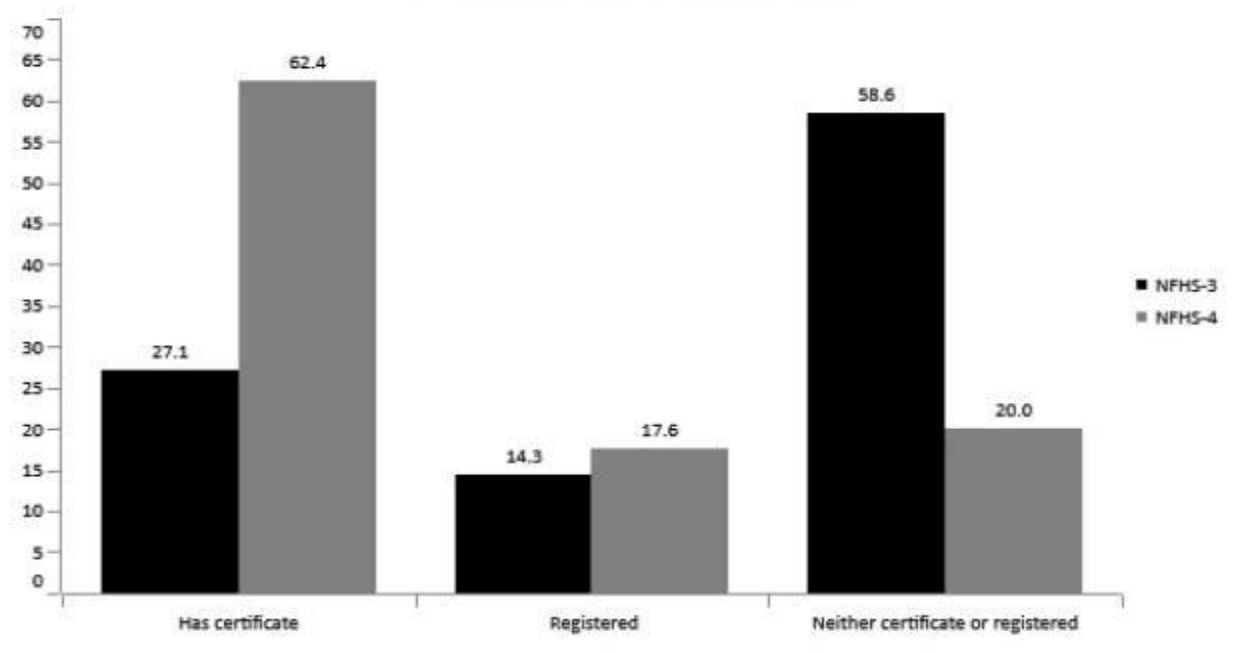

